\title{
Significant Others, Family Responsibility and the Freedom of the African Child in Tsitsi Dangarembga's Nervous Conditions
}

\author{
Prof (Mrs.) Grace Eche Okereke \\ University of Calabar, Nigeria \\ geokereke@yahoo.com \\ Dr (Mrs.) Itang Ede Egbung \\ University of Calabar, Nigeria \\ itangede@yahoo.com
}

Doi:10.5901/mjss.2014.v5n20p2059

\begin{abstract}
This paper interrogates the way the exercise of authority and sense of responsibility by significant others in the family impact on the freedom of the African child - female and male in Tsitsi Dangarembga's Nervous Conditions (1989). It analyses the interplay of culture, gender and westernization as mediating factors in positioning adults and children, men and women, boys and girls in the family and in informing their sense of responsibility. The paper analyses how these factors help to construct the consciousness, choices and responses of the male and female child characters to the impositions of significant others parents, grandparents, uncles, aunts, brothers, sisters, cousins and close family friends in the selected novel. The paper also examines the strategies adopted by the girl child characters to resist the efforts of these significant others to invade their identities and violate their sense of freedom. It also investigates the consequences of the child characters' struggles to protect their individuality, right to exist and choose, right to speak, grow and develop especially in the African cultural context. All of these thematically and stylistically engage the child characters - girls and boys - in Tsitsi Dangarembga's Nervous Conditions (1989).
\end{abstract}

Keywords: Significant Other, Family Responsibility, Freedom, African Child

\section{Introduction}

In Africa, especially the traditional context, children are of great value and constitute the primary reason for marriage. But male children are valued more highly than female children because they secure the lineage through procreation, while the female children marry and leave their natal homes and are, therefore, seen as a loss to their families. This amounts to what Lopez (2008) terms "gender apartheid" (qtd in Okuyade 114). This differential valuation informs the differential treatment of male and female children and impact on the rights of the child in the home. This paper investigates these contentions in Tsitsi Dangarembga's Nervous Conditions by analyzing the way significant others relate with male and female children in the process of executing their perceived family responsibilities and how this impacts on the freedom of the child.

\section{Analysis}

In Tsitsi Dangarembga's Nervous Conditions (NC) the child characters who will form the focus of this paper are Nhamo and Chido for male children and Nyasha and Tambudzai (Tambu) for female children. The significant others who owe the child responsibility are Tambu's grandmother, Jeremiah and Mainini, (Tambu's and Nhamo's parents), Babamukuru and Maiguru, (Nyasha and Chido's parents), who are also uncle and aunt to Nhamo and Tambu. These will form the focus of the analysis although others who are not so central may be mentioned as necessary.

Both the "United Nations Convention on the Rights of the Child" and The "OAU Charter on the Rights and Welfare of the Child" define a child as "every human being below the age of 18 years" (Olakanmi 2010, 58, 83). When Nervous Conditions opens, Tambu is thirteen years old and when it ends she is about sixteen years old; Nyasha is also in her teens. The narrative of the vicissitudes of the life of the child, especially the girl child, is told by Tambu , the protagonist, in flashback. The story opens with the death of Nhamo and so Nhamo is not physically present when the narrative begins. 
Tambu, the narrator, uses layers of flashback, going down memory lane to resurrect Nhamo and bring his character back to life on the pages of the novel. Tambu, as first person narrator, tries to narrate the events of her childhood as she experienced them as a child, but this is done with the maturity and judgment of an adult mind because she tells the story in retrospect. This redeems the story from the naivety and innocence naturally inherent in the child's perspective by conferring on it the complex readings and interrogation of adult behaviour and its impact on the child.

The venom in the opening sentence of the novel - "I was not sorry when my brother died"(NC 1) - articulates the offended psyche of the protagonist, Tambu, as a girl child who has suffered discrimination and oppression in the hands of the significant others in her life because of her sexuality, her being female. As a child, Tambu learns to her chagrin that gender and sexuality inextricably intersect in defining the way the significant others execute their family responsibility towards her as a female child and her brother as a male child. Both "United Nations Convention on the Rights of the Child" and the "OAU Charter on the Rights and Welfare of the Child" enumerate the rights of the child to include right to education, parental care and protection, expression, etc (Olakanmi 2010, 58, 84). However, African culture discriminates against the girl child in favour of the boy child in the execution of these rights in the day-to-day affairs of the family. This can be observed in the differential treatment meted to boys and girls in the same household by the significant others, as exemplified in Nervous Conditions. In the Jeremiah Sigauke household, Nhamo as a male child is singled out for preferential treatment and given the privilege of living at the mission with his father's elitist educated brother, Babamukuru, to facilitate his education. He thus enjoys escape from the poverty of the homestead, whereas Tambu and her little sisters have to work hard till evening with their mother on the farm and thereafter attend to the cooking and other domestic chores.

Because of the favouritism that her parents and uncle confer on Nhamo, he perceives himself as culturally and naturally superior to Tambu and his sisters, thus fuelling his arrogance and high-handedness which inflict on Tambu a feeling of being cheated and oppressed in her home at a very early age. Although the law states that "every child shall have the right to education" (Olakanmi 84), there is a tacit cultural assumption in Africa that, in the face of lean resources, the girl child's education is sacrificed on the altar of her brother's. This is what happens when Babamukuru, the economic mainstay of the family, travels to England with his family for further studies. Tambu's mother, Mainini, sells her produce and "scraped together enough money to keep my brother (Nhamo) in school" (NC 15), but Tambu has to drop out of school though she "loved going to school and... was good at it" (NC 15).

Tambu's father, unable to live up to his responsibility of paying his daughter's school fees, seeks escape in patriarchal culture's view of the girl child's primary cultural utility as being groomed into a prospective good wife. This is articulated in Jeremiah's oppressive question and myopic counsel to Tambu: "Can you cook books and feed them to your husband? Stay at home with your mother, learn to cook and clean. Grow vegetables" (NC 15). It is inevitable that Tambu feels there is an oppressive conspiracy to rob her of her rights and short-change her in life by not only her brother but with the collusion of the adults (her parents), the significant others in her life. Okuyade(2009) recognizes this conspiracy and Tambu's response to it as he notes that "Destined as a woman not to aspire beyond the limitation of her subservient domestic roles, Tambu liberates herself by transcending the social and traditional space constructed for women" (123).

Mainini, Tambu's mother, is helpless as a significant other in Tambu's predicament in the face of the cultural subjugation of the girl child, for she, like her daughter, is also a victim, although she is an informed victim. Although she is not educated, Tambu's mother is highly conscious of the female predicament in a patriarchal African world like Zimbabwe. She philosophically articulates this predicament to Tambu:

This business of womanhood is a heavy burden.... How could it not be? Aren't we the ones who bear children...? When there are sacrifices to be made, you are the one who has to make them. And these things are not easy; you have to start learning them early, from a very early age.... And these days it is worse, with the poverty of blackness on one side and the weight of womanhood on the other. Aiwa! What will help you, my child is to learn to carry your burdens with strength $(N C$ 1989, 16).

The above is reminiscent of the "double yoke" that plagues Nko in Buchi Emecheta's Double Yoke as identified again by the girl child's mother, who, like Tambu's mother, warns Nko: "...Daughter, you know what you are under, you are under a double yoke. So you need a stronger shoulder with which to carry it"' (Double Yoke 1982, 94). These mothers in the African traditional context may be unschooled in formal western education, but they are certainly wise in the ways of their burdensome marital worlds in patriarchal culture. They recognize the challenge that sexuality poses to the female's freedom and destiny both as an adult and as a child in Africa.

The failure of Tambu's parents as significant others in their responsibility to educate her, puts great pressure on Tambu to provide her fees, amounting to what Doris, the white woman, describes as "slavery" as she painfully grows and sells maize to raise money for her fees. Worse still, Jeremiah exploits his young daughter by scheming to appropriate the ten pounds Doris donates towards her education. Tambu's father is depicted as a very irresponsible uncaring father $-\mathrm{a}$ 
negative portrait of the most significant other in the upbringing and development of the child. Jeremiah's egotism is anchored on the fact that in the cultural psyche, an educated and economically powerful Tambu will marry one day and all of that investment will be a loss to her natal family. This informs the reason for parents preferring to educate the male child in the event of lean family resources. However, contemporary realities have shown that it is actually the female children who often serve as economic succours to their aging parents, as is the case with the daughters of Musa Dogo who redeem him from poverty and misery in Zaynab Alkali's The Virtuous Woman (1987) although he refused to educate them(51). Elsewhere we have stated that "In Nervous Conditions, Tambu achieves relevance in her family through educational attainment, she becomes the redeemer of her family from poverty" ( Egbung \& Okereke 2009, 51).

Another notable significant other who impacts on the life of Tambu is her grandmother. The grandmother figure has a stake in the upbringing of the child in African culture. As a mother to her uncle, Babamukuru, Tambu's grandmother is a woman of vision and foresight. Like Ezeulu in Chinua Achebe's Arrow of God (1974) who sent his son, Oduche, "to join these people [the colonial masters] and be my eye there" (45), she had strategized to locate her son (Babamukuru) at the age of nine in the power structures of colonial and post-colonial Africa "to prepare him for life in their world" (NC 19). Therefore, as mother to Babamukuru, Tambu's grandmother did her job well by sending him to live with the colonial masters thus ensuring a bright future for her son. Babamukuru's professionally, socially and economically empowering position as headmaster of the Mission school sets him up as a model to Tambu and whets her hunger for education. To her, it is a necessary tool for the girl child's emancipation from poverty, deprivation and patriarchal subjugation. This is because education equips the girl child with not only awareness and knowledge of her rights but also with economic independence.

In her desperate quest for money for her education, Tambu, through flashback, pays a befitting tribute to the memory of her grandmother whose legacy of work served as a motivating force for her: "When I was too small to be anything more than a hindrance in the family fields, I used to spend many productive hours working with my grandmother on the plot of land she called her garden.... Praising my disposition towards working, she consolidated it in me as a desirable habit" (NC 17). Tambu's grandmother as a significant other initiates her into the ethic of work that equips the African woman for a life of self-reliance and independence. It is this refusal to depend on a man for survival that defines the African woman's feminism. Filomina Steady articulates this in her submission that "True feminism is an abnegation of male protection and a determination to be resourceful and reliant. The majority of the black women in Africa and the diaspora have developed these characteristics, though not always by choice..." (qtd. in Davies \& Graves 1986, 7). Although Tambu's grandmother is dead, the legacy of productive labour she inculcated in her redeems her from the frustration of depending on her feckless father for her education. While Tambu's working with her grandmother in the farm may be seen as child abuse by the West, in the African context it is not an infringement on the rights of the child. It is rather viewed as a commendable lesson in the child's upbringing and development.

Indeed, Tambu's grandmother fills the intellectual vacuum created by her mentally and physically indolent father, Jeremiah. Tambu's inquisitiveness and mental agility contrasts sharply with her father's intellectual apathy and vacuity. While her father is "agitated" (NC 34) because she is reading a sheet of newspaper, her grandmother, while they worked in the farm, "... gave (her) history lessons.... History that could not be found in textbooks" (NC 17). Thus Tambu's grandmother functions well as a significant other in executing the family responsibility of empowering Tambu with the important narratives she needs to locate herself in the multi-dimensional colonial and post-colonial sexual and cultural politics. As I have asserted elsewhere:

Significantly, it is while working hard on the land (the site of colonial struggle and the engendering of history), that Tambu's grandmother reconstructs and articulates her family's history of Western exploitation and land dispossession, migration and survival, and her own story of gender power.... The episodes of 'herstory' unwind in synchrony with the rhythm of work. Thus it is in affinity with the ecosystem that Tambu's grandmother appropriates orality, voice and power to tell the female story (Okereke 2004, 65-66).

Tambu's grandmother is, then, instrumental in executing one of the fundamental rights of the girl child - first-hand education on her heritage - which ironically her more modern parents cannot give her. She needs this education to understand the authentic undocumented version of her past, in order to be able to locate herself in the present and define herself in the immediate and distant future.

Another very significant other in the lives of the children in Nervous Conditions is Babamukuru. He impacts the growth and development, indeed the very existence, of both the boy and girl children in the novel. When his children Chido and Nyasha - are very young, Babamukuru's authoritativeness and total control of their lives are in order as he has their welfare at heart and they are still too young to make their own choices. As an African parent, he is mindful of the wellbeing of his children and so would not travel to England with his wife for further education without them. This protectiveness is a positive attribute of most African parents. However, Chido and Nyasha's exposure to British culture 
which allows the child multi-dimensional freedom under the law, and their attainment of greater awareness as they develop and grow physically and mentally, set them towards a collision course with their patronizing authoritarian father. Babamukuru may have flourished and reaped bountifully from the colonial authorities who educated him as a child by submitting to their code of conduct of "endure and obey, for there is no other way"(NC 19). But the same code of conduct and expectations from his own children in post-colonial Zimbabwe (Africa) will not yield the same positive result. It rather breeds conflict, familial disharmony, violence and disaster because times have changed.

Babamukuru's desperate paternalistic agenda to control his daughter, Nyasha, "who is torn between two conflicting cultures" (Egbung 2013, 141), becomes psychologically oppressive to her, leading to a revolt with dire consequences on her mental and physical health. Nyasha's mental agility and precocious intelligence, her knack for asking uncomfortable questions and ability to fearlessly dissect situations unpretentiously, set her apart as a free and rebellious female spirit who will not be contained even by a tyrannical, pugilistic, violent father. Her non-conformism and resistance of cultural correctness is exasperating to her father, Babamukuru, who by his position and image as the benevolent, idolized, family patriarch insists on cultural correctness in every area of life.

Babamukuru flies into a murderous rage and brutalizes Nyasha verbally and physically, calling her "a whore"(NC 114) just for staying out late at a party and speaking to a white boy. This psychological, emotional and physical brutalization is anchored on Nyasha's sexuality - she is treated like this because she is an unmarried female child, whereas her brother, Chido, is free to go and come and relate with whoever he wills. Tambu realizes that Nyasha's femaleness is at the root of this paternal control and curtailing of the girl child's freedom which amounts to a violation of her rights. Tambu's insightful understanding of the multi-dimensional oppression of the girl child in Africa is articulated in her analysis of the situation thus:

\begin{abstract}
...I [was] feeling bad for her and thinking how dreadfully familiar that scene had been, with Babamukuru condemning Nyasha to whoredom, making her a victim of her femaleness, just as I had felt victimised at home in the days when Nhamo went to school and I grew my maize. The victimisation, I saw, was universal. It didn't depend on poverty, on lack of education or on tradition. It didn't depend on any of the things I had thought it depended on. Men took it everywhere with them. Even heroes like Babamukuru did it. And that was the problem.... But what I didn't like was the way all the conflicts came back to this question of femaleness. Femaleness as opposed and inferior to maleness (NC 115-116).
\end{abstract}

To Babamukuru, Nyasha is guilty of all the negative behaviours that are unacceptable from a child, especially a female child, in African culture - hitting her father, talking back at him, challenging his authority, displaying self-sufficiency and independence and enduring fourteen lashes without breaking down to beg him, smoking, mixing freely with boys etc. But to Nyasha these are non-issues most of which are her responses to her father's oppression and strategies for her self-preservation.

Nyasha fighting her father, Babamukuru, though an abomination in African culture, signifies not only the fight for freedom for the girl child; it is also an existentialist fight for her right to exist, to be herself and to resist being consumed by the significant others who want to appropriate her life under the guise of executing family responsibility for the good of the child. While Tambu prefers to compromise and acquiesce to Babamukuru's paternalism and domination, in order to survive, develop and maximize the opportunities available to her under Babamukuru's tutelage at the mission, Nyasha will not compromise her freedom. She rather chooses to fight her father's domination, abusiveness and battery.

Nyasha, as a cultural hybrid, finds herself a victim at the crossroads of English and African cultures resulting in unresolvable conflicts. Her parents who exposed her to English culture and its brazenness, experience first-hand its collision with her African cultural background and a collision between her (Nyasha's) convictions and their expectations. As significant others, they fail in their responsibility to their daughter because, instead of helping her to negotiate her conflicting consciousnesses, they are the most vehement and brutal in judging and condemning her. Nyasha articulates her dilemma and its trauma when she tells Tambu: "Look at me now. I was comfortable in England but now l'm a whore with dirty habits"' (NC 117). Nyasha has a mind of her own which propels her to fight for her rights and freedom. This rebellion of the girl child, the patriarchal psyche cannot accommodate because it is threatening to it. This is especially troubling for the super patriarch - Babamukuru - who considers himself the alpha male of the Sigauke family. Nyasha stands her ground to resist mental and psychological colonization by her father.

Nyasha's ultimate revolt against her father Babamukuru's violation of her individuality and sense of freedom is expressed through the eating disorder she suffers. In her father's presence, Nyasha robotically overstretches herself to please him by gulping down the food to avoid his volcanic temper and verbal, sometimes physical, attacks. But immediately she leaves his presence, her rebellion and resistance of his oppressive authority manifest in her forcing the food out of her system. Nyasha's anorexia nervosa becomes a physical reaction to her traumatized psychological state. As she internalizes her pain, Nyasha withdraws into herself and is pulled into opposite directions by the conflicts arising 
from the contradictions and pressures that define her life. This results in extreme loneliness, indeed, alienation. Nyasha's nervous breakdown and psychological crisis express themselves in her raging against western values and the multidimensional colonization of Africans which she is exposed to first-hand through her colonized parents - Babamukuru and Maiguru. Tambu reports Nyasha's rage: "She rampaged, shredding her history book between her teeth ('Their history. Fucking liars. Their bloody lies.'), breaking mirrors, her clay pots, anything she could lay her hands on and jabbing the fragments viciously into her flesh..."(NC 201).

There is no redeeming Nyasha from her predicament as Maiguru (her mother) is afraid, Tambu (her cousin) is helpless and Babamukuru (her father) is too wrapped up in his egotistic self-deification and authoritarianism to even notice his daughter's plight. When Nyasha faints under Babamukuru's oppressive pressures at table, it is shocking that he is offended because he thinks she is "making a scene" (NC 200) and punishes her by sending her to her room. Babamukuru is blind to the danger his daughter is in signaling his myopia and insensitivity as a father. It is also alarming that the white psychiatrist, with all his knowledge and professional experience, dismisses Nyasha's case without properly attending to her after a myopic and shallow assessment of the situation. The gender and cultural stereotyping of Nyasha as female and African respectively, constitutes a barrier to her being understood by her father and the white psychiatrist as a unique individual with special personal needs that transcend these stereotypes. All these point to the gross failure of significant others in their responsibility to ensure the health, wellbeing, mental and psychological stability of the child, especially the female child. Nyasha's crier de coeur is like a scream in a dark, nightmarish void with no end in sight. The fact that Babamukuru is more concerned with his image and authoritarian position as headmaster who has "a school to keep in order" (NC 202) and so is "anxious to be back in Umtali" (NC 202), while his daughter is in danger and hospitalized, is indicting, and projects him as an uncaring father who has failed woefully in his paternal responsibilities.

Tambu's friendship and understanding provide the solace, the therapeutic presence Nyasha needs in this failure of her parents to protect her from harm. Nyasha and Tambu's mutual, symbiotic dependence on each other configure them as important to each other in the business of life. They help each other to cope with the vagaries and disappointments of life. As Tambu gives expression to her own narrative of family discrimination and oppression which she suffered as a girl child in the homestead, both she and Nyasha comprehend that the female story is a narrative of pain anchored on patriarchal society's inferiorisaton and imprisonment of her destiny in her sexuality, her body. This female narrative is "the same everywhere" (NC 118) - there are only variations of the same story.

The letters Nyasha writes to Tambu who is physically away to the Convent school, provide an outlet for her troubled mind for a while. But when they stop altogether, the emotional dam builds up and is bound to burst with disastrous consequences. Tambu's absence dislodges the emotional prop that had helped Nyasha to contain her destabilizing fury against her controlling, meddling father and her weak unhelpful mother. The consumptive effect of Tambu's quest for education and her increasing responsibilities in the pursuit of it, rob Nyasha of Tambu's stabilizing presence and its therapeutic effect at a time that Nyasha needs it most. Tambu rationalizes her failure in her role as a peer significant other for her cousin, Nyasha, with a callous though tangible reason: "I felt Nyasha needed me but... I had to go back to school" (NC 202).

Tambu, on the other hand, is secure under Babamukuru's tutelage only as she obeys him and conforms to his expectations. But the moment she rebels especially in her rejection of the ludicrous wedding that Babamukuru, in his skewed view of sin and punishment, imposes on her parents, Babamukuru sees Tambu as a "bad" and "ungrateful" child who does not respect him or appreciate his benevolence. Tambu bares her mind on the wedding: "...I did not want to go to that wedding. A wedding that made a mockery of the people I belonged to and placed doubt on my legitimate existence in this world" (NC 163). Her out-of-body experience is a psychological reaction to Babamukuru's imposition and a concrete denial of the sordid reality in which she is enmeshed. Her split consciousness creates a double which helps Tambu deal with the sordid realities which her real self cannot handle. Tambu's refusal to attend her parents' wedding and play the role of a bridesmaid, signals her rebellion against Babamukuru's obnoxious paternalistic control of her and her parents which is an infringement on her freedom. Okuyade (2009) argues that "Her absence from the wedding is not only an act of defiance, but the demystification and debunking of patriarchal codes which Babamukuru represents" (121). This earns her severe punishment - fifteen lashes (since she is fifteen years old) - and two weeks of doing the maid's domestic chores. For Tambu, this punishment is the price she has to pay for her incipient revolt towards freedom, as she tells us: "I went about these chores grimly, with a deep and grateful masochistic delight: to me that punishment was the price of my newly acquired identity" (NC 169).

As a mother and aunt to Nyasha and Tambu respectively, Maiguru is a significant other to the two girls. But she is weak, being herself a victim of her husband Babamukuru's authoritarianism. Maiguru cannot defend or shield Nyasha from her father's patriarchal invasion and violation of her freedom, for her daughter is a stronger character than she is. Maiguru's helplessness as she watches Babamukuru's circumscription of Nyasha's freedom, because of her fractured 
sexual and cultural identity and her insistence on not compromising her rights and her freedom, is symbolized in her escapist self-infantilism signaled by her cooing baby language. In contrast to Nyasha, her mother cannot successfully rebel against Babamukuru's exploitation and multi-dimensional confinement of her destiny. Ironically, education does not automatically ensure emancipation for Maiguru from the exploitative and paternalistic male establishment epitomized in her husband Babamukuru. It is only the radical Lucia, Mainini's sister and Tambu's aunt, who possesses the boldness to contradict and challenge the asphyxiating male establishment in favour of the individuality and freedom of the woman and the girl child. And because of this boldness, Babamukuru describes Lucia as being "like a man" (NC 171). In the patriarchal psyche, the bold woman is perceived as behaving like a man, because boldness is stereotyped as a male attribute.

Communication, that is talk, is a very important building block in constructing harmonious and stable family relationships. This should cut across all situations, levels, genders and ages. But ironically, silence which symbolizes lack of communication is seen as a sign of respect from the child to elders in African culture. So if the child cannot discuss issues with the significant other because this is considered disrespectful and rude, how will the adult know the problems, challenges etc. confronting the child, her perspective on important issues in her life and welfare, let alone find workable solutions to them. It is significant that Babamukuru and Nyasha never have a healthy conversation in the course of the narrative of Nervous Conditions. What they have are what Tambu calls "bloody family scenes" (120) characterized by disease, verbal terrorism, and sometimes, physical violence. This communication gap signals that both the children and the significant others are living and functioning in two divergent, sometimes, clashing worlds. The chasm created leads to misunderstanding, misrepresentation and misinterpretation of issues; indeed, it leads to "nervous conditions" and breakdowns with loss of freedom especially for the girl child.

Maiguru as the mother of the house communicates more in different family contexts with the children. If Maiguru had adopted the position of a wise catalyst in her communication strategies with her husband and children in mediating their conflicts, she would have functioned better as the sane centre that holds the different conflicting views and personalities together in harmony. But Maiguru sees herself as primarily responsible to upholding Babamukuru's position as the infallible family patriarch, whose views must be respected and whose commands must be obeyed. Only twice does Maiguru revolt against Babamukuru by contesting his views, as she speaks up against the myth of the educated woman as loose (immoral) in defence of embattled womanhood in relation to Tambu going to the mission school. The other time is when she rebels against her husband's exploitation of her economic worth for the benefit of his family. Though her rebellion is short-lived and male-defined (as she runs to her brother), at least her intervention on behalf of Tambu constrains Babamukuru to allow her to attend the mission school.

The contrasting quests that engage Nyasha and Tambu in their process of development determine and inform their self-location in the fight for freedom as girl children in Nervous Conditions. While Nyasha fits into the image of homo sapience in her higher quest for greater knowledge and wisdom, directed towards defining her identity as an individual, Tambu is concerned with a lower quest for economic emancipation casting her into the image of homo economicus which is directed towards material empowerment. The background of each of the female children dictates her unique quest. Nyasha's wealthy, elitist background as well as her analytic, progressive mind and rebellious personality predispose her to a higher rebellious intellectual quest, while Tambu's background of poverty, illiteracy and dependence impose on her a survival mentality leading to a lower mundane utilitarian quest for economic sufficiency.

Babamukuru serves as a model for Tambu in her quest for economic empowerment having himself travelled the same road, thereby mortgaging her fight for freedom. On the other hand, Nyasha's precocity and rebellious spirit launch her ahead of her colonized father, her husband-controlled mother and her security-seeking cousin. Since she has no adult significant other as a model except, perhaps, to an extent, the unschooled but radical Lucia, Nyasha has to blaze her own trail by treading the lonely path of rebellious non-conformity, to the hot displeasure of her conventional selfrighteous father and the discomfort of her educated but docile mother.

Nyasha's challenging legacy of resistance, and Mainini's disturbing analysis of the consumptive dis-ease of cultural alienation (caused by the educated Africans' progressive consumption of concentrated doses of Englishness and their sudden inability to speak their mother tongue - Shona), sow seeds of frightening awareness in Tambu. This leads to Tambu's transformation from an acquiescent pursuer of economic power, who trades her identity in exchange for a little space to belong among the assimilated, to a rebel who could "no longer ....accept Sacred Heart and what it represented as a sunrise on my horizon" (NC 203). It has indeed been a liberating journey because, through it, Tambu begins to grow from homo economicus to homo sapience, from the mundane quest for economic power to the higher quest for freedom and self-definition. Udumukwu (2007) notes that "Tambu's story can be seen as a girl's innate desire to be freed from a condition of unhappy consciousness" (94). The novel ends with Tambu narrating her new location as an emerging informed, independent consciousness making her own new choices no longer directed by the values of her uncle, 
Babamukuru: "Quietly, unobtrusively and extremely fitfully, something in my mind began to assert itself, to question things and refuse to be brainwashed... it was a long and painful process for me, that process of expansion" (NC 204).

The story of Tambu and Nyasha articulate the challenges confronting the girl child in the process of growing up in traditional and colonial Africa. It is an environment where the child has no practical rights beyond those which the significant others in her life confer on her. Hers is a double oppression anchored on her age and sexuality, as child and female. To survive, she must work out her own strategies to negotiate the cultural, gender and generational challenges and impositions on her by male and female significant others who are meant to protect her and safeguard her welfare. While the strategies of Nyasha who is ahead of her time are ill-timed and too radical and fail to safeguard her survival, Tambu successfully employs different strategies that work in different circumstances to ensure her survival. Tambu's rebellion and self-application to earn her fees to continue her education help her to successfully negotiate her survival of gender discrimination in favour of her brother at the homestead. But with Babamukuru, Tambu employs compromise and submission as survival strategies. She employs the strategy of stooping to conquer until she is multi-dimensionally prepared to launch a more confrontational struggle against sexual and mental colonization as symbolized in her father, her brother and Babamukuru on one hand and western colonial education on the other hand. It is significant that she lives and, unlike Nyasha, is psychologically stable enough to tell her story as she symbolically states: "...But the story I have told here, is my own story..." (NC 204).

Tambu's ability to tell her own story, to articulate the female child's bildungsroman, signifies her victory in the fight for freedom, her victory over the silencing agenda of significant adults who demand respect and robotic, unquestioning obedience at the expense of the girl child's self-definition and happiness in the family context. Ironically the family context as a space of intimacy privileges speaking one's mind without fear of vulnerability and rejection. But the Jeremiahs, Babamukurus and Maigurus use the weapon of psychological intimidation to shut the girl child up. This silencing strategy makes Nyasha, the forthright, outspoken non-conformist child, to painfully interiorize the contradictions of her world with damaging physical and psychological effects. And when she can no longer bottle them up, they spill out into a destructive rampage - madness - which ultimately leads to her multi-dimensional confinement and total loss of freedom.

\section{Conclusion}

At the end of the novel the girl child has attained some liberation through her personal struggle - Nyasha through hyper awareness leading to unmitigated revolt culminating in madness (signaling withdrawal from the sordid realities of her world), and Tambu through caution and incipient awareness leading to the developing of a questioning mind, en route to rejecting sexual and mental colonization as epitomized in Babamukuru and her western colonial education (the Convent School). It is understandable that in Nervous Conditions, this struggle for freedom to be herself, to grow and develop in a limiting African cultural environment against the tidal wave of significant others (whose very zeal to execute their responsibility towards the child in this context signals their failure), is not an issue for the boy child, whereas it is the girl child's herculean struggle for her identity, her individuality, indeed, her destiny, her freedom.

It is pertinent to note that the girl child in Nervous Conditions tells the different strands of the female story. Tambu's is a resisting voice which is heard narrating the painful experiences of the girl child in the process of growing up in an incarcerating patriarchal environment - Zimbabwe. As Tambu tells these stories, every detail of discrimination, oppression, brutalization and paternalism, resonates with pain, asphyxiation, struggle and, ultimately, rebellion when the girls can no longer endure. Pathetically, the girls' mothers cannot protect them as they are themselves victims of their husbands' authoritarianism. These oppressed mothers - Mainini and Maiguru - escape respectively in garrulity and the cooing baby language and chirpy birdlike communication style. These images of infantilism associated with the female adult serve the male view of the woman as an unintelligent weakling who cannot pose a threat to his authority. For the female children in Nervous Conditions, the journey of growing up in the male-dominated African culture is marked by an existential quest for self-definition and personal freedom. It is a journey through the thicket of "nervous conditions" of patriarchal impositions fraught with anxiety and dis-ease but leading to the rare aroma of incipient freedom for the girl child.

\section{References}

Achebe, C. (1974). Arrow of God. London: Heinemann.

Alkali, Z. (1987). The Virtuous Woman. Ikeja: Longman.

Dangarembga, T. (1989). Nervous Conditions. Seattle: The Seal Press.

Davies, C. (1986). Introduction: Feminist Consciousness and African Literary Criticism. In C. Davies, \& A. Graves (Eds.), Ngambika: 
Studies of Women in African Literature (pp. 1-23). Trenton: Africa World Press.

Egbung, I. \& Okereke, G. (2009). Education as an Equalizer: A study of Bessie Head's Maru and Tsitsi Dangarembga's Nervous Conditions. CALEL: Currents in African Literature and the English Language, vol. 6, 47-56.

Egbung, I. (2013). Paternalism and Family Relationships in Tsitsi Dangarembga's Nervous Conditions and Chimamanda Adichie's Purple Hibiscus. NDUNODE: Calabar Journal of the Humanities, vol 10, num. 1, 136-148.

Emecheta, B. (1982). Double Yoke. London: Ogwugwu Afor.

Okereke, G. (2004). Orality, Gender Vocality and Revolt in Tsitsi Dangarembga's Nervous Conditions. CALEL: Currents in African Literature and the English Language, 2.1, 64 -73.

Okuyade, O. (2009). Washing the Childhood from their Eyes: Recent African Narratives and the Politics of Growth. CALEL: Currents in African Literature and the English Language, vol. 6, 110-125.

Olakanmi, J. (2010). Handbook on Human Rights. (2nd ed.). Abuja: Lawlords Publication.

Udumukwu, O. (2007). Signature of Women: The Dialectics of Action in African Women's writing. Owerri: Onii Publishing House. 